\title{
'Omic approaches to preventing or managing metastatic breast cancer
}

\author{
Obi L Griffith' and Joe W Gray ${ }^{1,2 *}$
}

\begin{abstract}
Early detection of metastasis-prone breast cancers and characterization of residual metastatic cancers are important in efforts to improve management of breast cancer. Applications of genome-scale molecular analysis technologies are making these complementary approaches possible by revealing molecular features uniquely associated with metastatic disease. Assays that reveal these molecular features will facilitate development of anatomic, histological and blood-based strategies that may enable detection prior to metastatic spread. Knowledge of these features also will guide development of therapeutic strategies that can be applied when metastatic disease burden is low, thereby increasing the probability of a curative response.
\end{abstract}

\section{Introduction}

Metastatic disease is the major cause of breast cancer mortality and is typically resistant to conventional and experimental therapies. The 5 -year survival rate for metastatic breast cancer remains below $25 \%$ [1]. It is imperative to develop breast cancer management strategies that are based on detection and treatment before or soon after metastatic spread [2] in order to improve this situation. Mammographic screening strategies are intended to accomplish this by detecting cancers before metastatic dissemination. Such screening has been successful for both colon [3] and cervical [4-6] cancers but results for breast cancer are less positive. The widespread introduction of population-based screening breast mammography beginning in the mid 1980s resulted in a dramatic rise in the detection of stage 1 cancers as well as ductal carcinoma in situ. However, treatment of these patients

\footnotetext{
*Correspondence: jwgray@|bl.gov

'Lawrence Berkeley National Laboratory, Life Sciences Division, Cancer and DNA

Damage Responses, One Cyclotron Road, Berkeley, CA 94720, USA

Full list of author information is available at the end of the article
}

has not resulted in the expected decrease in mortality, indicating that screening breast mammography misses critical lesions until after they have spread [7]. In fact, a recent study of over 40,000 Norwegian women with breast cancer showed that while screening was associated with a $10 \%$ reduction in the rate of death from breast cancer, only one-third of this improvement could be attributed directly to screening [8]. Balanced against this modest improvement in overall survival are the dangers of over-treatment with the attending therapy-linked morbidities. This suggests that current screening strategies are not detecting metastasis-prone lesions before metastatic spread has occurred and are detecting many lesions that will not progress to metastatic disease [9] or may even regress spontaneously [10]. This may be due to lack of sensitivity to metastasis-prone breast cancers and/or progression during the interval between mammographic screenings. Thus, improved screening strategies 'tuned' specifically to detect metastasis-prone cancers are needed that are both more sensitive and sufficiently affordable for frequent use. In the unfortunate event that breast cancer does become metastatic, sensitive and subtype-specific disease detection strategies also may improve outcome by allowing subtype-specific, targeted therapy to begin when recurrent disease burden is smaller.

Global analyses of epigenomic, genomic, transcriptional and proteomic (hereafter referred to as 'omic') changes that occur during progression to metastatic disease suggest candidate molecular markers that might be used as the basis for early detection assays. These changes occur during a multi-step process that allows subpopulations of the primary tumor and subsequent disseminated cells to escape their primary site and establish elsewhere [11]. This process may include omic changes that enable mobilization, invasion, angiogenesis, epithelial-to-mesenchymal transition, vascular remodeling, intravasation, immune evasion, extravasation, and organ-specific colonization [12]. In cancer stem cell models, only a small persistent population of cells accrue the necessary mutations and are responsible for relapse and metastasis through a stem-cell-like process of differentiation and self-renewal [13]. In any case, omic studies 


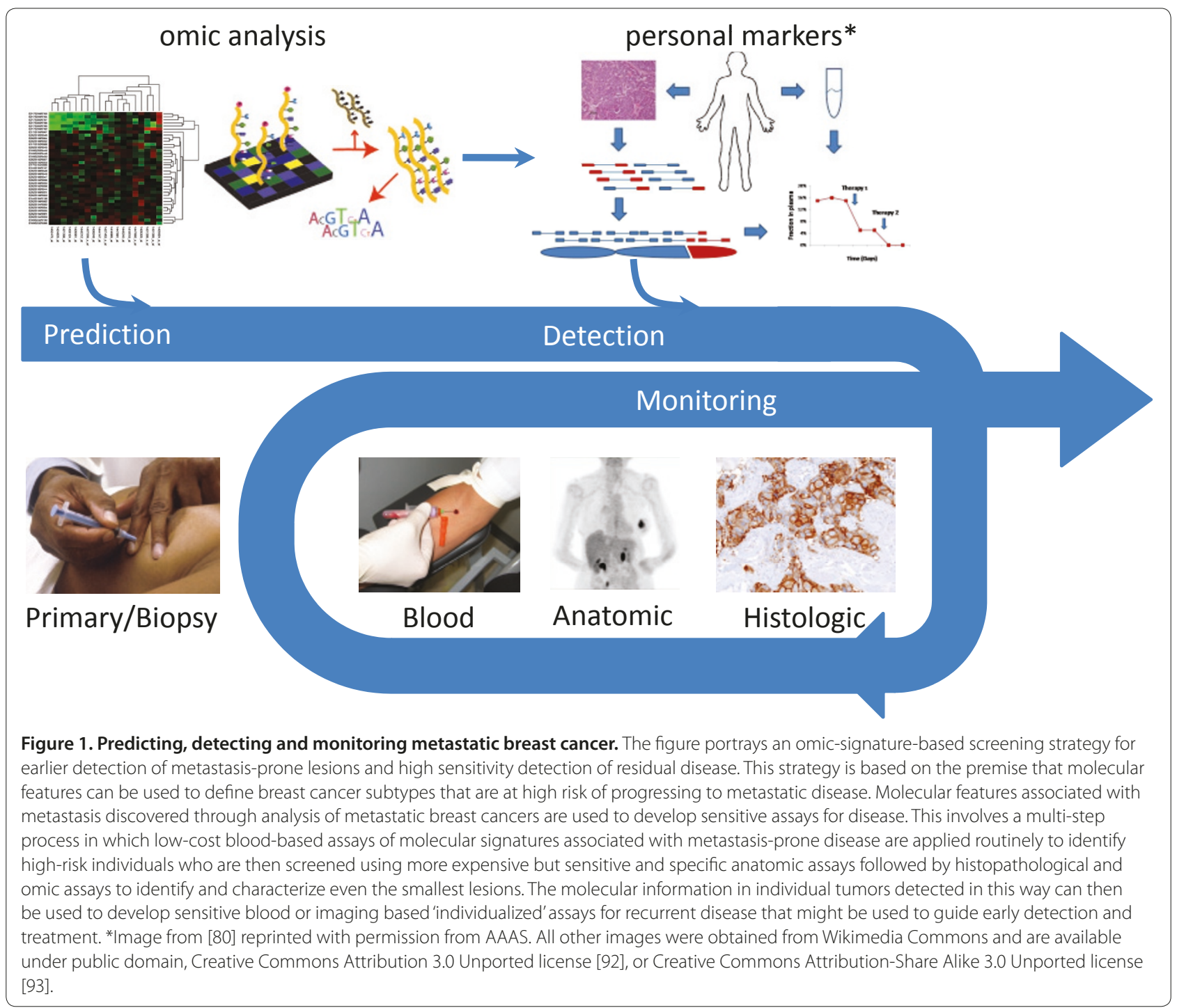

to date suggest that some breast cancer subtypes are more metastasis-prone than others. For example, basal and luminal $\mathrm{B}$ tumors are more likely to progress to metastatic disease than luminal A tumors [14]. This suggests that omic characteristics of metastasis-prone cancers can be used to develop strategies that will detect these aggressive cancers before significant cancer dissemination has occurred.

Figure 1 suggests an omic-signature-based screening strategy that we believe will lead to earlier detection of metastasis-prone lesions and to high sensitivity detection of residual disease. An omic-signature refers to a molecular marker or panel of markers, useful for clinical decision making, determined by large-scale measurement at various omic levels, such as the genome (gene and regulatory sequences), epigenome (epigenetic modifications), transcriptome (RNA and gene expression), proteome (protein expression) and others. This is a multistep screening process in which (a) low-cost blood-based assays of molecular signatures associated with metastasisprone disease are applied routinely to identify high-risk individuals, (b) more expensive but sensitive and specific anatomic assays are used to localize the lesions, and (c) molecular histopathological omic assays are used to identify and determine the molecular characteristics of even the smallest lesions. The molecular information in individual tumors detected in this way can then be used to develop sensitive blood- or imaging-based 'individualized' assays that might be used to enable early detection and treatment of recurrent disease.

Development of the strategies outlined above will require an extensive understanding of the molecular features of metastasis-prone breast cancers and of metastatic disease in sites around the body. Breast cancers 
commonly spread to local lymph nodes, bone, lungs, liver, brain and other sites. Patterns of metastasis may be related to the molecular subtype of the tumor, with estrogen receptor (ER)-positive luminal-like cells spreading preferentially to bone and ER-negative and basal-like tumors preferentially spreading to visceral organs $[15,16]$. Many genes have been identified that act as oncogenes or tumor suppressor genes, allowing proliferation, resistance to death signals, angiogenesis, altered cell adhesion and motility [17]. Changes in these genes mediate initiation and local progression of tumors and are prerequisites for metastasis. However, fewer genes have been identified for the subsequent steps of 'metastasis proper' [18]. Genes that act as mediators of metastasis could be activated by many genetic and epigenetic mechanisms. Identifying metastasis-prone breast cancers, detecting residual metastatic cancer early and intervening effectively will likely require a detailed understanding of these specific changes.

Discovery of molecular features associated with metastasis is increasingly possible through the application of advanced DNA, RNA and protein (omic) analysis technologies that reveal molecular features associated with these aspects of metastasis. Omic characterization of breast cancers has been underway for over a decade and is accelerating as a result of technological advances made during the course of international genome analysis efforts. Initial developments were stimulated by the Human Genome Project $[19,20]$ and have been accelerated by work in The Cancer Genome Atlas (TCGA) project [21] and in the International Cancer Genome Consortium (ICGC) [22]. We review here recent progress in elucidating the molecular features of metastatic breast cancer with the idea that this information can be used eventually to guide the development of assays suggested in Figure 1.

\section{Prediction: signatures for metastasis Molecular subtypes}

Much of the effort to predict outcome in breast cancer (Table 1) has focused on the definition of molecular subtypes, some of which have a high likelihood of progressing to metastasis. Important markers such as ER, progesterone receptor and human epidermal growth factor receptor 2 (HER2) have long been used to predict response to treatment and define important subclasses of breast cancer. Now, omic analyses are leading to multigene expression signatures that further define breast cancer subtypes as basal, luminal A, luminal B, normallike [23] and claudin-low [24]. These distinct molecular subtypes display different clinical behaviors and outcomes. For example, patients with basal-like breast cancers are prone to more aggressive metastatic relapse whereas patients with luminal A cancers generally have good long-term outcome [23,25]. The 50-gene PAM50 signature was developed to standardize breast cancer subtyping using a 189 sample training set and was tested in 761 patients receiving no systemic therapy and 133 patients treated with a taxane and anthracycline. These studies showed that the signature also added prognostic and predictive information to standard parameters for patients with breast cancer [26]. Other gene expression signatures, including the genomic grade index (GGI) [27] and molecular grade index (MGI) [28], are complementary to histologic grade and have been used to identify additional distinct subtypes in ER-positive disease $[28,29]$. The GGI can be used as a predictor of survival and has been associated with response to chemotherapy [30].

\section{Prognostic signatures}

Some gene signatures have been developed specifically to predict the risk of relapse, distant metastasis or response to specific therapies $[31,32]$. These include the 21-gene Oncotype Dx signature [33], the 70-gene MammaPrint signature [34] and the 76-gene Rotterdam signature [35]. Only a few genes are shared between these signatures and yet they perform comparably when applied to similar patient data and all improve risk assessment. Oncotype Dx is used to predict risk of relapse and response to treatment for patients with lymph-node-negative and ER-positive disease. Patients in the low-risk group have significantly better outcome than those in the high-risk group and more patients can be put into this low-risk group (approximately 50\%) than with traditional risk assessment methods (for example, St Gallen criteria) [33]. Oncotype recurrence score is also predictive of degree of benefit from adjuvant chemotherapy [36]. The Mammaprint signature was originally validated in a cohort of 234 premenopausal women with no systemic therapy [37]. Patients in the high-risk group had significantly lower rates of overall 10-year survival and distant metastasis-free survival. Mammaprint's utility has since been further demonstrated in post-menopausal women [38]. Mammaprint has been shown to be a useful predictor of metastasis even in tumors otherwise thought to have good prognosis [39]. Most recently, studies have shown predictive value for response to both neoadjuvant [40] and adjuvant [41] chemotherapy. A cost-benefit study showed that Mammaprint improves quality-adjusted survival and will be cost-effective compared to St Gallen guidelines and the Adjuvant Online Software for assessing prognosis [42]. The 76-gene Rotterdam signature is particularly relevant to detection of metastasis-prone cancers since it was developed to predict metastatic spread in lymph-node-negative patients [35]. It was originally developed using a training set of 115 lymphnode-negative patients and tested in a test set of 171 
Table 1. Selected expression signatures potentially useful for predicting metastasis-prone breast cancer

\begin{tabular}{|c|c|}
\hline Signature & Description \\
\hline $\begin{array}{l}\text { Molecular subtype } \\
{[23,24]}\end{array}$ & $\begin{array}{l}\text { Breast tumors can be partitioned into distinct molecular subtypes such as basal-like, luminal, HER2-positive, normal-like, } \\
\text { claudin-low and others with distinctly different clinical behaviors and outcomes using global or multi-gene expression signatures }\end{array}$ \\
\hline PAM50 [26] & $\begin{array}{l}\text { A 50-gene signature developed to standardize breast cancer subtyping. This study showed that the signature added prognostic } \\
\text { and predictive information to standard parameters for patients with breast cancer }\end{array}$ \\
\hline $\begin{array}{l}\text { Histologic grade } \\
\text { (GGI [27]; MGI [28]) }\end{array}$ & $\begin{array}{l}\text { Gene expression signatures correlated with histologic grade, such as the genomic grade index (GGI) and molecular grade index } \\
(\mathrm{MGI}) \text {, can be complementary to histologic grade and used to predict survival and response to chemotherapy }\end{array}$ \\
\hline $\begin{array}{l}\text { Oncotype DX } \\
\text { (Genomic Health) [33] }\end{array}$ & $\begin{array}{l}\text { A 21-gene signature initially developed to determine risk of relapse and response to chemotherapy in ER-positive and } \\
\text { lymph-node-negative patients }\end{array}$ \\
\hline $\begin{array}{l}\text { Mammaprint } \\
\text { (Agendia) [34] }\end{array}$ & $\begin{array}{l}\text { A 70-gene signature initially developed for pre-menopausal women but subsequently also found useful for post-menopausal } \\
\text { women for prediction of risk of metastasis and chemotherapy response }\end{array}$ \\
\hline $\begin{array}{l}\text { Rotterdam (Veridex, } \\
\text { Johnson \& Johnson) [35] }\end{array}$ & A 76-gene signature that predicts risk of distant metastasis in lymph-node-negative (ER-positive or ER-negative) patients \\
\hline SET index [47] & $\begin{array}{l}\text { A } 165 \text {-gene signature correlated with ER that predicts response to adjuvant endocrine therapy independent of general } \\
\text { prognosis }\end{array}$ \\
\hline DLDA30 [49] & A 30-gene predictor of sensitivity to T/FAC chemotherapy \\
\hline $\begin{array}{l}\text { Genomic instability } \\
{[52-54]}\end{array}$ & $\begin{array}{l}\text { Several expression signatures correlated with measures of genomic instability have been developed and determined to be } \\
\text { predictors of poor prognosis and metastasis }\end{array}$ \\
\hline Wound [55] & A 512-gene signature that characterizes the response of fibroblasts to serum and is predictive of metastasis and death \\
\hline Hypoxia [56] & A 253-gene signature characterizing hypoxia response that is predictive of clinical outcomes in breast and ovarian cancers \\
\hline Invasion [57] & $\begin{array}{l}\text { A 186-gene signature developed by comparing tumorigenic and non-tumorigenic breast cancer cells as defined by expression of } \\
\text { cell-surface proteins CD44 and CD24 or epithelial-specific antigen and CD10; associated with overall survival and metastasis-free } \\
\text { survival }\end{array}$ \\
\hline $\begin{array}{l}\text { Lung-specific } \\
\text { metastasis [58] }\end{array}$ & $\begin{array}{l}\text { A 54-gene signature representing the differences between a parental breast cancer cell line and a derived line selected for ability to } \\
\text { metastasize specifically to lung. Individual genes and selected combinations were shown to promote lung metastasis when } \\
\text { over-expressed and the signature overall distinguishes between patients with high and low risk for lung metastasis }\end{array}$ \\
\hline
\end{tabular}

ER, estrogen receptor; HER2, human epidermal growth factor receptor 2.

lymph-node-negative patients. The gene signature identified patients at high risk of developing distant metastases within 5 years. It was validated subsequently in a multicenter evaluation of an additional 171 lymph-nodenegative patients [43]

\section{Signatures predicting response to specific agents}

Distinct from the purely prognostic signatures discussed above are signatures under development for the prediction of response to specific agents. Oakman and colleagues [31] have recently reviewed in detail the evidence for single gene markers of drug response. These include the use of HER2 and TOP $2 A$ amplification/expression to predict anthracycline response; $H E R 2$, protein tau, and $P 53$ to predict response to taxanes; and BRCA1 or the related basal-signature to predict response to DNA damaging agents. Others have reviewed multi-gene signatures for predicting sensitivity to specific agents $[44,45]$. Loi and colleagues [46] developed a 181-gene signature that separates patients based on outcome after adjuvant tamoxifen therapy. An advantage of this signature is that it was clustered in 13 clusters of highly correlated genes from which numerous different 13-gene signatures were evaluated and found to have nearly the same performance as the complete signature. The SET index, a set of 165 genes co-expressed with ER, was shown to predict survival benefit from adjuvant endocrine therapy [47]. This signature was not prognostic in untreated cohorts, indicating that it may specifically predict treatment benefit rather than simply correlate with better outcomes as do some others. The DLDA-30 signature has been shown to be predictive of pathologic complete response after pre-operative treatment with paclitaxel and a combination of fluorouracil, doxorubicin, and cyclophosphamide (T/FAC) with high sensitivity [48]. Validation studies have confirmed the ability of DLDA-30 to identify patients with higher than average sensitivity to T/FAC chemotherapy [49]. However, its performance was not significantly better than clinical variable-based predictors, raising an important metric for success of such signatures. Similar efforts are underway to develop multi-gene predictors of response to taxanes/anthracyclines [50], dasatinib [51], and others.

\section{Transcriptional signatures for metastasis and related biological themes}

Other signatures may provide more direct information about the biology of metastasis. For example, several gene expression signatures correlated with genomic instability have been found to be independent predictors 
of poor prognosis and metastasis [52-54]. A 512-gene 'wound signature' associated with the response of fibroblasts to serum across a wide range of anatomic sites [55] also predicts increased risk of metastasis and death in breast cancer. Other signatures with predictive potential for metastatic phenotype include a 253-gene 'hypoxia' signature [56] and a 186-gene 'invasion' signature [57]. A 'lung metastasis' signature [58] is even more directly related to the metastatic process. Serial in vivo selection of a breast cancer cell line (MDA-MB-231) produced a derivative line (LM2) that metastasized readily to the lung in mice. Comparison of the derivative line to the parental line identified a set of 54 differentially expressed genes. Over-expression of nine of these genes, singly and in combination, consistently increased aggressive metastatic activity and some combinations completely recapitulated aggressiveness of the LM2 line. Bone metastatic activity was not increased, confirming the tissuespecific functions of these genes. Down-regulation by RNA interference in LM2 cells decreased metastatic activity by more than ten-fold. The 54-gene signature distinguished between patients with high risk and low risk of lung metastasis. However, only 18 of the 54 genes were found to be expressed in primary tumors of breast cancer patients. This suggests that detection strategies for metastasis-prone cancers might best focus on genes activated at early stages that are directly involved in metastasis.

\section{Metastasis-related genomic events}

Detection strategies for metastasis-prone breast cancers may be improved by using genomic information, including copy number, promoter methylation and mutations. Massively parallel sequencing (MPS) projects, including the TCGA and the ICGC, are providing these data $[21,22]$. In breast cancer, mutations in BRCA1 and $B R C A 2$ are well established as important in the relatively rare familial breast cancers [59]. Other mutated genes in breast cancer reported in the Catalogue of Somatic Mutations in Cancer (COSMIC) database [60] include PIK3CA (25\% [61]), TP53 and CDH1 (22\%), PTEN (6\%), $A K T 1$ (5\%) and numerous mutations that occur at frequencies $<5 \%$. The roles of these mutations in metastatic progression are mostly unknown, although some are early events that may be useful as markers of residual disease. Importantly, several of these mutations, including in TP53 [62] and BRCA1 [14], are preferentially associated with the metastasis-prone basal subtype.

Early detection strategies based on genomic aberrations will be influenced by when these aberrations occur during evolution and metastasis. The mutational landscape in metastatic breast cancer has only just begun to be elucidated with two key papers recently published. One sequenced DNA from a basal-like primary breast tumor, subsequent brain metastasis, peripheral blood and a xenograft derived from the primary [63]. The second sequenced an ER-positive lobular breast tumor and subsequent pleural effusion [64]. The pleural effusion, collected 9 years after the primary tumor, contained 32 somatic non-synonymous coding mutations, of which 19 were unique to the metastasis, 6 enriched and only 5 prevalent in the primary. No somatic structural changes were identified. In contrast, the brain metastasis, collected less than a year after primary surgery, contained 50 mutations and 41 structural variations, of which only two mutations and a large deletion were unique to the metastasis. Copy number alterations were found to be both increased in number and expanded in metastatic tissue relative to the primary. It is possible that differences in the numbers of metastasis-specific mutations found between the two studies have as much to do with the intrinsic subtypes of the tumors as with timing. Larger studies will be needed to identify recurrent sequence changes relevant to the metastatic process and to determine when these changes occur. If possible, early detection methods should focus on aberrations present in the primary tumor that predispose to metastasis. Projects such as TCGA and ICGC are now providing a wealth of omic information on primary breast tumors $[21,22]$. However, analyses of primary/metastasis pairs will take longer as these samples are difficult to acquire and will require special effort. Efforts to chronologically order genomic aberrations may be facilitated by the development of strategies based on the structure of the genome in a single sample rather than by analyzing serial samples.

\section{Detection: the metastatic needle in the haystack}

It is likely that no single molecular feature will identify all metastatic lesions. Indeed, the signatures for metastatic basal and luminal subtype cancers may be completely different. In addition, stochastic genetic, environmental and microenvironmental factors may influence the molecular features of metastatic cancers. This suggests that assays for early detection of metastasis-prone cancers must assess multiple omic features. Ultimately, a tiered approach such as that depicted in Figure 1 will likely be needed, with blood-based tests used to identify patients with molecular features putting them at high risk of carrying metastasis-prone lesions followed by sensitive molecular imaging for anatomic localization.

\section{Blood-based detection Proteomic methods}

Plasma biomarkers are ideal for disease detection because they can be measured inexpensively for the general population to enable early disease detection. However, discovery of highly specific tumor biomarkers 
in the plasma is hampered by interference from a small number of highly abundant and absorbent proteins (for example, albumin) that make up $99 \%$ of the total protein mass in plasma [65]. For this reason, a prioritization step will be required to predict which biomarkers are most likely to be useful for blood-based screening so that enrichment strategies can be developed for these markers (see Box 1 for sample criteria). Candidates must then be validated in plasma-based assays. Traditional assays such as ELISA typically require expensive and time-consuming development for each potential candidate and thus represent an important bottleneck in the discovery pipeline [65]. New high-throughput methods are being developed to overcome this bottleneck, particularly targeted mass spectrometry (MS) methods such as selected reaction monitoring MS (SRM-MS). These approaches are similar to standard MS but can be 'tuned' to look for specific peptides using knowledge of the expected $\mathrm{m} / \mathrm{z}$ based on in silico digestion of candidate proteins (for example, those identified as associated with metastasis). Spiking known quantities of isotope-labeled proteins of interest allows quantification of the endogenous protein. Sensitivity can be further improved by enrichment steps with affinity reagents, allowing detection of protein biomarkers down to $100 \mathrm{pg} / \mathrm{ml}$. A further derivation of the method, multiple reaction monitoring MS (MRM-MS), is achieved by monitoring several different SRM transitions within one MS run, allowing simultaneous measurement of multiple proteins or protein isoforms [66]. This method allows multiple low abundance proteins to be quantified simultaneously with excellent accuracy and reproducibility [67]. MRM-MS can even be used to measure phosphorylation stoichiometry and recent proof of principle experiments have measured both phosphorylation and total protein abundance of critical breast cancer biomarkers such as ER and HER2 [68]. Few studies have yet applied these methods specifically to breast cancer metastasis. In one example, however, liquid chromatography MS was used to compare plasma membrane protein abundances between metastatic and non-metastatic breast cancer cells in a mouse model. A total of 1,919 proteins were detected and of these, 13 were differentially expressed. Subsequent validation in clinical breast cancer biopsies found a significant association between high CD73 or integrin $\beta 1$ and poor outcome [69]. Mining of the metastatic proteome will likely be a critical step in the development of blood-based biomarkers for both prediction of metastatic outcome and monitoring of residual disease and treatment response.

\section{Circulating tumor cells and disseminated tumor cells}

Disseminated tumor cells (DTCs) in the bone marrow or lymph nodes or circulating tumor cells (CTCs) in the

\section{Box 1. Criteria to select markers for blood-based screening \\ Association with metastasis: In order to be predictive markers for metastasis, the marker must be somehow specific to metastatic cells. This specificity could be a quantitative difference (for example, increase in measurable transcript, protein, and so on) or a qualitative difference (alternative splice form, fusion product, mutation, post-translational modification, and so on).}

Mechanistic: ideal markers would be causally related to some aspect of metastatic progression, therefore serving both as biomarkers and potential therapeutic targets.

Highly expressed: ideal markers will be highly expressed in metastatic lesions making detection easier.

Readily assayed and measurable: An assay must exist that can (preferably) quantitatively measure the marker. Also, the marker must be accessible to the assay in the blood. Thus, biomarkers that are located on the cell surface or secreted are favored.

Stable against degradation: Markers should be stable in the blood so that infrequent assays will be able to detect their presence. Based purely on stability, this might argue for prioritization of DNA over protein and protein over RNA.

Multi-gene, multi-assay: Individual markers are not likely to be sufficient. Accurate and sensitive detection may require multimarker assays and separate assays for different disease subtypes.

blood represent other opportunities for early disease detection or recurrence monitoring. Detection typically involves an initial enrichment step, such as gradient centrifugation or immunomagnetic separation, used together with either positive selection for CTCs (for example, by epithelium-specific antibodies such as antiepithelial cell adhesion molecule (EpCAM)) or by negative depletion of hematopoietic cells (for example, by antibodies against CD45) [70]. Differentiation of DTCs/ CTCs is then performed by immunocytochemistry or PCR-based techniques [71,72]. To date, most commercial systems are based on immunological approaches. These have the advantage of detecting DTCs/CTCs and also providing metrics such as cell size, shape and staining patterns. Primary issues with these assays are relatively low sensitivity and the fact that the epithelial antigens typically used for detection may not be expressed on all tumor cells [73]. Alternative antibodies such as anti-cytokeratins can increase sensitivity [74] but again may vary between tumors. Molecular PCR-based approaches offer increased sensitivity but are dependent on detection of known mutations, amplifications or methylation patterns.

Several studies have shown an association between the presence of DTCs in the bone marrow and metastatic relapse in breast cancer [72]. Approximately 30\% of women with primary breast cancer harbor DTCs in their bone marrow even in the absence of overt metastasis and these patients have worse prognosis than those without 
DTCs detected [75]. The presence of extensive bone metastases has been associated with increased CTC numbers in metastatic breast cancer [76]. A prospective multicenter trial of patients with metastatic breast cancer found that about half of all patients had detectable CTCs using the CellSearch ${ }^{\odot}$ assay and about $40 \%$ were positive using AdnaTest BreastCancer ${ }^{\mathrm{TM}}$ [77]. More interestingly, up to half of patients with HER2-negative primary tumors had HER2-positive CTCs. This suggests that HER2 status can change during breast cancer progression or relapse and raises the possibility that monitoring of CTCs for such markers could inform targeted treatment of metastasis. There remains, however, a troublingly poor concordance between CTC assay methods. Development of consistent CTC detection methods and standard HER2 (and other biomarker) assessment methods is still needed. Another challenge is that CTCs can lie dormant for years and have been detected in patients with metastasis-free survival over 20 years after primary diagnosis [78]. Thus, simple detection of CTCs alone may not be sufficient to identify clinically important metastatic disease or determine the correct treatment. Indeed, studies have shown that only a subset of DTCs/CTCs detected are viable and that many are simply terminal or dead tumor cells shed from the primary or metastasis and do not necessarily directly represent metastatic cells (reviewed in [79]).

\section{Circulating tumor DNA}

MPS also holds the promise of personalized and sensitive detection of recurrent disease by measuring the characteristics of circulating tumor DNA. Leary and colleagues [80] report the use of MPS to screen primary tumors for patient-specific structural rearrangements followed by PCR-based assessment of plasma DNA using primers that flank the aberration breakpoints. This method, termed 'personalized analysis of rearranged ends' (PARE), identified tumor-specific biomarkers that can be used to monitor response to therapy, assess residual disease and/or monitor for relapse. Two breast (along with four colorectal) tumors were analyzed using this approach. At least four somatic rearrangements were confirmed in each tumor (five and fifteen in the two breast tumors). All were unique with no recurring rearrangements between any of the six tumors. Plasma blood from two of the colorectal cancer patients was assayed by digital PCR analysis and the presence of one rearrangement each was successfully detected. For one patient, blood was available at several time points, allowing the tracking of mutant DNA fraction as it sharply decreased after surgery, rebounded and then decreased again after chemotherapy and removal of metastatic lesions. A small non-zero detection level remained after all treatments, consistent with known residual metastatic disease in the remaining left lobe of the liver. A recent survey of 24 breast cancer genomes by MPS found substantial variation in the number of observed rearrangements from 1 to 231 (median 38) in primaries and 58 to 245 (median 101) in cell lines [81]. This demonstrates the general potential for personalized detection and monitoring of disease by a sensitive and quantitative method. Such methods could ultimately be complemented by equally personalized therapeutic approaches. Recently, the first example of clinical application of whole genome/transcriptome analysis described a MPS analysis of a rare adenocarcinoma of the tongue and subsequent metastases to the lung and skin [82]. The observation of amplification and up-regulation of RET and downstream pathway members was used to inform clinical selection of RET inhibitor therapy with some apparent success. However, such cases remain anecdotal.

\section{Anatomic detection}

Detection of breast cancer by molecular imaging techniques has been reviewed extensively elsewhere [83] but will be discussed briefly here. Proton magnetic resonance spectroscopy (MRS) is one of the most established techniques. While MRI uses the signal from hydrogen protons to form anatomic images, proton MRS uses this information to determine the concentration of metabolites. For example, MRS focused on choline metabolites can be used to detect malignant breast disease at a sensitivity of $80 \%$ and specificity of $100 \%$ [84]. Imaging methods that focus specifically on detecting metastasis are less common but still plentiful. A recent metaanalysis compared ultrasound, computed tomography, MRI, scintimammography and positron emission tomography (PET) for their abilities to detect breast cancer recurrence or metastasis [85]. For the 42 studies included, ultrasound and MRI had the highest specificity $(0.962$ and 0.929) and MRI and PET had the best sensitivity (0.950 and 0.953). They concluded that MRI was the most useful supplement to standard surveillance techniques but recommended fluorodeoxyglucose (FDG)-PET for cases where MRI was indeterminate or unavailable. It should be noted that the pooled detection accuracies reported are likely overly optimistic. In most cases the reason for performing imaging was suspicion of recurrence from other indicators; thus, the population was enriched for recurrences. The studies also included local recurrences, which are easier to detect than distant micrometastasis. In any case, this analysis demonstrated a high potential accuracy for detection of breast metastasis by several imaging modalities.

The metastasis-prone triple-negative subtype of breast cancer can be detected with high sensitivity using FDGPET and shows a distinctly enhanced FDG uptake compared to other subtypes [86]. Breast-specific gamma 
imaging and FDG positron emission mammography show promise in finding small invasive cancers with reported sensitivities of 79 to $96 \%$ [83]. MRI can detect lymph node metastasis with excellent specificity (100\%) and positive predictive value (100\%) [87]. Recent reports have demonstrated that whole-body MRI can be performed in approximately 1 hour and provide 'diagnostically adequate' detection of breast cancer metastases [88]. The study looked at 19 breast cancer patients with known metastases using whole-body, Dixon-based multisequence and multiplanar MRI. The procedure was well tolerated by 18 out of 19 patients, took only $69 \pm 5$ minutes of patient time, and image quality was graded as good to excellent by radiologists. A number of different histologically proven metastases were detected. It remains to be seen whether the method can detect de novo metastasis and whether such detection can actually improve outcomes. However, applying these techniques for assessment of patients at high risk of metastatic disease indicated by blood-based screening methods seems promising.

While these imaging methods are getting better at detecting malignant from benign or normal tissues, more work is needed for the detection of micrometastases. Sensitive detection methods targeting the molecular features of metastasis revealed by omic analyses are needed. Biomarkers from metastatic signatures may allow the development of targeted contrast reagents to improve imaging of breast metastasis. Targeted contrast reagents are created by the conjugation of imaging tracer molecules (such as quantum dots, radiotracers, fluorophores, and so on) with affinity-based targeting molecules (such as nucleic acids, proteins, antibodies, antibody fragments, or engineered affibodies) that target a biological molecule of interest (reviewed in [89]). In principal, the most attractive features for this purpose are cell surface proteins that are uniquely represented or particularly highly expressed in the metastasis-prone cells. Such agents can be used in conjunction with MRI, PET, X-ray, transmission electron microscopy and other imaging modalities. For example, in mice xenografts, a targeted contrast reagent composed of ${ }^{18} \mathrm{~F}$ radiotracer and a HER2 affibody was recently shown to allow in vivo monitoring of HER2 expression levels by PET [90]. Similar metastasis-specific agents might someday allow whole-body sensitive detection and monitoring of metastatic lesions. Work in this area is still in the early stages of development but should be effectively guided by the omic analyses described above that are revealing highly expressed cell surface molecules that are associated with metastasis and/or reduced survival duration.

\section{Conclusion}

Metastatic disease is a major challenge for breast cancer management. Improvements in outcome may come either from improving treatment strategies or by identifying and treating metastasis-prone breast cancers before metastatic dissemination has occurred. The latter strategy is promising since modern omic analysis procedures are now providing molecular descriptors of metastasisprone cancers. This information should guide development of the required sensitive blood-and imaging-based detection strategies. Sensitive, subtype-specific tumor detection strategies also may allow earlier detection and treatment of recurrent disease. Methods for earlier detection of recurrent disease already exist, but to date there has been no identified benefit of monitoring for distant relapse since metastatic disease remains essentially uncurable. In fact, American Society of Clinical Oncology (ASCO) published guidelines for breast cancer follow-up and management do not include any recommendations for detection/screening beyond history and physical examination [91]. However, detection strategies that identify molecular features that suggest therapies likely to be effective in the screened individual may change the currently dismal situation.

\section{Abbreviations}

CTC, circulating tumor cell; DTC, disseminated tumor cell; ELISA, enzymelinked immunosorbent assay; ER, estrogen receptor; FDG, fluorodeoxyglucose; GGI, genomic grade index; HER2, human epidermal growth factor receptor 2; ICGC, International Cancer Genome Consortium; MGl, molecular grade index; MPS, massively parallel sequencing; MRI, magnetic resonance imaging; MRM, multiple reaction monitoring; MRS, magnetic resonance spectroscopy; MS, mass spectrometry; $P C R$, polymerase chain reaction; $P E T$, positron emission tomography; SRM, selected reaction monitoring; TCGA, The Cancer Genome Atlas.

\section{Competing interests}

Joe Gray serves on Scientific Advisory Boards for Agendia, Cepheid, KromaTiD and New Leaf ventures.

\section{Acknowledgments}

This work was supported by the Director, Office of Science, Office of Biological and Environmental Research, of the US Department of Energy under contract number DE-AC02-05CH11231, by the Department of the Army, award W81XWH-07-1-0663, the National Institutes of Health, National Cancer Institute grants P50 CA 58207, the U24 CA 126477, and the Canadian Institutes of Health Research. The content of the information does not necessarily reflect the position or the policy of the Government, and no official endorsement should be inferred.

\section{Author details}

'Lawrence Berkeley National Laboratory, Life Sciences Division, Cancer and DNA Damage Responses, One Cyclotron Road, Berkeley, CA 94720, USA ${ }^{2}$ Oregon Health and Science University, Biomedical Engineering Department, 3303 SW Bond Ave, Portland, OR 97239, USA.

\section{Published: 8 December 2011}

\section{References}

1. Altekruse SF, Kosary CL, Krapcho M, Neyman N, Aminou R, Waldron W, Ruhl J, Howlader N, Tatalovich Z, Cho H, Mariotto A, Eisner MP, Lewis DR, Cronin K, Chen HS, Feuer EJ, Stinchcomb DG, Edwards BK: SEER Cancer Statistics Review, 1975-2007. Bethesda, MD: National Cancer Institute; 2010.

2. Etzioni R, Urban N, Ramsey S, McIntosh M, Schwartz S, Reid B, Radich J, Anderson G, Hartwell L: The case for early detection. Nat Rev Cancer 2003, 3:243-252.

3. Jemal A, Clegg LX, Ward E, Ries LA, Wu X, Jamison PM, Wingo PA, Howe HL, Anderson RN, Edwards BK: Annual report to the nation on the status of 
cancer, 1975-2001, with a special feature regarding survival. Cancer 2004, 101:3-27.

4. Laara E, Day NE, Hakama M: Trends in mortality from cervical cancer in the Nordic countries: association with organised screening programmes. Lancet 1987, 1:1247-1249.

5. Johannesson G, Geirsson G, Day N: The effect of mass screening in Iceland, 1965-74, on the incidence and mortality of cervical carcinoma. Int J Cancer 1978, 21:418-425

6. Sigurdsson K: Effect of organized screening on the risk of cervical cancer. Evaluation of screening activity in Iceland, 1964-1991. Int J Cancer 1993, 54:563-570.

7. Tabar L, Fagerberg G, Duffy SW, Day NE, Gad A, Grontoft O: Update of the Swedish two-county program of mammographic screening for breast cancer. Radiol Clin North Am 1992, 30:187-210.

8. Kalager M, Zelen M, Langmark F, Adami HO: Effect of screening mammography on breast-cancer mortality in Norway. N Eng/ J Med 2010, 363:1203-1210.

9. Jorgensen KJ, Gotzsche PC: Overdiagnosis in publicly organised mammography screening programmes: systematic review of incidence trends. BMJ 2009, 339:b2587.

10. Zahl PH, Maehlen J, Welch HG: The natural history of invasive breast cancers detected by screening mammography. Arch Intern Med 2008 $168: 2311-2316$

11. Hunter KW, Crawford NP, Alsarraj J: Mechanisms of metastasis. Breast Cancer Res 2008, 10 Suppl 1:S2.

12. Chiang AC, Massague J: Molecular basis of metastasis. N Engl J Med 2008, 359:2814-2823.

13. Kraljevic Pavelic S, Sedic M, Bosnjak H, Spaventi S, Pavelic K: Metastasis: new perspectives on an old problem. Mol Cancer 2011, 10:22.

14. Sorlie T, Tibshirani R, Parker J, Hastie T, Marron JS, Nobel A, Deng S, Johnsen H, Pesich R, Geisler S, Demeter J, Perou CM, Lønning PE, Brown PO, BørresenDale AL, Botstein D: Repeated observation of breast tumor subtypes in independent gene expression data sets. Proc Natl Acad Sci U S A 2003, 100:8418-8423.

15. Luck AA, Evans AJ, Green AR, Rakha EA, Paish C, Ellis IO: The influence of basal phenotype on the metastatic pattern of breast cancer. Clin Oncol (RColl Radiol) 2008, 20:40-45

16. Kennecke H, Yerushalmi R, Woods R, Cheang MC, Voduc D, Speers CH, Nielsen TO, Gelmon K: Metastatic behavior of breast cancer subtypes. J Clin Oncol 2010, 28:3271-3277.

17. Futreal PA, Coin L, Marshall M, Down T, Hubbard T, Wooster R, Rahman N, Stratton MR: A census of human cancer genes. Nat Rev Cancer 2004, 4:177-183.

18. Nguyen DX, Massague J: Genetic determinants of cancer metastasis. Nat Rev Genet 2007, 8:341-352.

19. Lander ES, Linton LM, Birren B, Nusbaum C, Zody MC, Baldwin J, Devon K, Dewar K, Doyle M, FitzHugh W, Funke R, Gage D, Harris K, Heaford A, Howland J, Kann L, Lehoczky J, LeVine R, McEwan P, McKernan K, Meldrim J, Mesirov JP, Miranda C, Morris W, Naylor J, Raymond C, Rosetti M, Santos R, Sheridan A, Sougnez $C$, et al: Initial sequencing and analysis of the human genome. Nature 2001, 409:860-921.

20. Venter JC, Adams MD, Myers EW, Li PW, Mural RJ, Sutton GG, Smith HO, Yandell M, Evans CA, Holt RA, Gocayne JD, Amanatides P, Ballew RM, Huson DH, Wortman JR, Zhang Q, Kodira CD, Zheng XH, Chen L, Skupski M, Subramanian G, Thomas PD, Zhang J, Gabor Miklos GL, Nelson C, Broder S, Clark AG, Nadeau J, McKusick VA, Zinder N, et al.: The sequence of the human genome. Science 2001, 291:1304-1351.

21. The Cancer Genome Atlas Research Network: Comprehensive genomic characterization defines human glioblastoma genes and core pathways. Nature 2008, 455:1061-1068.

22. International Cancer Genome Consortium, Hudson TJ, Anderson W, Artez A Barker AD, Bell C, Bernabé RR, Bhan MK, Calvo F, Eerola I, Gerhard DS, Guttmacher A, Guyer M, Hemsley FM, Jennings JL, Kerr D, Klatt P, Kolar P, Kusada J, Lane DP, Laplace F, Youyong L, Nettekoven G, Ozenberger B, Peterson J, Rao TS, Remacle J, Schafer AJ, Shibata T, Stratton MR, et al.: International network of cancer genome projects. Nature 2010, 464:993-998.

23. Sørlie T, Perou CM, Tibshirani R, Aas T, Geisler S, Johnsen H, Hastie T, Eisen MB, van de Rijn M, Jeffrey SS, Thorsen T, Quist H, Matese JC, Brown PO, Botstein D, Eystein Lønning P, Børresen-Dale AL: Gene expression patterns of breast carcinomas distinguish tumor subclasses with clinical implications. Proc
Natl Acad Sci U S A 2001, 98:10869-10874

24. Herschkowitz Jl, Simin K, Weigman VJ, Mikaelian I, Usary J, Hu Z, Rasmussen KE, Jones LP, Assefnia S, Chandrasekharan S, Backlund MG, Yin Y, Khramtsov Al, Bastein R, Quackenbush J, Glazer Rl, Brown PH, Green JE, Kopelovich L, Furth PA, Palazzo JP, Olopade Ol, Bernard PS, Churchill GA, Van Dyke T, Perou $\mathrm{CM}$ : Identification of conserved gene expression features between murine mammary carcinoma models and human breast tumors. Genome Biol 2007, 8:R76

25. Perou CM, Sørlie T, Eisen MB, van de Rijn M, Jeffrey SS, Rees CA, Pollack JR, Ross DT, Johnsen H, Akslen LA, Fluge O, Pergamenschikov A, Williams C, Zhu SX, Lønning PE, Børresen-Dale AL, Brown PO, Botstein D: Molecular portraits of human breast tumours. Nature 2000, 406:747-752

26. Parker JS, Mullins M, Cheang MC, Leung S, Voduc D, Vickery T, Davies S, Fauron C, He X, Hu Z, Quackenbush JF, Stijleman IJ, Palazzo J, Marron JS, Nobel AB, Mardis E, Nielsen TO, Ellis MJ, Perou CM, Bernard PS: Supervised risk predictor of breast cancer based on intrinsic subtypes. $J$ Clin Oncol 2009, 27:1160-1167.

27. Sotiriou C, Wirapati P, Loi S, Harris A, Fox S, Smeds J, Nordgren H, Farmer P, Praz V, Haibe-Kains B, Desmedt C, Larsimont D, Cardoso F, Peterse H, Nuyten D, Buyse M, Van de Vijver MJ, Bergh J, Piccart M, Delorenzi M: Gene expression profiling in breast cancer: understanding the molecular basis of histologic grade to improve prognosis. J Natl Cancer Inst 2006, 98:262-272.

28. Ma XJ, Salunga R, Dahiya S, Wang W, Carney E, Durbecq V, Harris A, Goss P, Sotiriou C, Erlander M, Sgroi D: A five-gene molecular grade index and HOXB13:IL17BR are complementary prognostic factors in early stage breast cancer. Clin Cancer Res 2008, 14:2601-2608.

29. Loi S, Haibe-Kains B, Desmedt C, Lallemand F, Tutt AM, Gillet C, Ellis P, Harris A Bergh J, Foekens JA, Klijn JG, Larsimont D, Buyse M, Bontempi G, Delorenzi M, Piccart MJ, Sotiriou C: Definition of clinically distinct molecular subtypes in estrogen receptor-positive breast carcinomas through genomic grade. $J$ Clin Oncol 2007, 25:1239-1246.

30. Liedtke C, Hatzis C, Symmans WF, Desmedt C, Haibe-Kains B, Valero V, Kuerer H, Hortobagyi GN, Piccart-Gebhart M, Sotiriou C, Pusztai L: Genomic grade index is associated with response to chemotherapy in patients with breast cancer. J Clin Oncol 2009, 27:3185-3191.

31. Oakman C, Bessi S, Zafarana E, Galardi F, Biganzoli L, Di Leo A: Recent advances in systemic therapy: new diagnostics and biological predictors of outcome in early breast cancer. Breast Cancer Res 2009, 11:205.

32. Kim C, Paik S: Gene-expression-based prognostic assays for breast cancer. Nat Rev Clin Oncol 2010, 7:340-347

33. Paik S, Shak S, Tang G, Kim C, Baker J, Cronin M. Baehner FL, Walker MG Watson D, Park T, Hiller W, Fisher ER, Wickerham DL, Bryant J, Wolmark N: A multigene assay to predict recurrence of tamoxifen-treated, nodenegative breast cancer. N Engl J Med 2004, 351:2817-2826.

34. van't Veer $L J$, Dai $H$, van de Vijver MJ, He YD, Hart AA, Mao M, Peterse HL, van der Kooy K, Marton MJ, Witteveen AT, Schreiber GJ, Kerkhoven RM, Roberts C, Linsley PS, Bernards R, Friend SH: Gene expression profiling predicts clinical outcome of breast cancer. Nature 2002, 415:530-536.

35. Wang Y, Klijn JG, Zhang Y, Sieuwerts AM, Look MP, Yang F, Talantov D, Timmermans M, Meijer-van Gelder ME, Yu J, Jatkoe T, Berns EM, Atkins D, Foekens JA: Gene-expression profiles to predict distant metastasis of lymph-node-negative primary breast cancer. Lancet 2005, 365:671-679.

36. Paik S, Tang G, Shak S, Kim C, Baker J, Kim W, Cronin M, Baehner FL, Watson D, Bryant J, Costantino JP, Geyer CE Jr, Wickerham DL, Wolmark N: Gene expression and benefit of chemotherapy in women with node-negative, estrogen receptor-positive breast cancer. J Clin Oncol 2006, 24:3726-3734.

37. van de Vijver MJ, He YD, van't Veer $L$, Dai H, Hart AA, Voskuil DW, Schreiber GJ, Peterse $J$ L, Roberts C, Marton MJ, Parrish M, Atsma D, Witteveen A, Glas A, Delahaye L, van der Velde T, Bartelink H, Rodenhuis S, Rutgers ET, Friend SH, Bernards R: A gene-expression signature as a predictor of survival in breast cancer. N Engl J Med 2002, 347:1999-2009.

38. Mook S, Schmidt MK, Weigelt B, Kreike B, Eekhout I, van de Vijver MJ, Glas AM, Floore A, Rutgers $E J$, van ' $t$ Veer $L J$ : The 70-gene prognosis signature predicts early metastasis in breast cancer patients between 55 and 70 years of age. Ann Oncol 2010, 21:717-722.

39. Mook S, Knauer M, Bueno-de-Mesquita JM, Retel VP, Wesseling J, Linn SC Van't Veer LJ, Rutgers EJ: Metastatic potential of $\mathrm{T} 1$ breast cancer can be predicted by the 70-gene MammaPrint signature. Ann Surg Oncol 2010, 17:1406-1413.

40. Straver ME, Glas AM, Hannemann J, Wesseling J, van de Vijver MJ, Rutgers EJ, 
Vrancken Peeters MJ, van Tinteren H, Van't Veer LJ, Rodenhuis S: The 70-gene signature as a response predictor for neoadjuvant chemotherapy in breast cancer. Breast Cancer Res Treat 2010, 119:551-558.

41. Knauer M, Mook S, Rutgers EJ, Bender RA, Hauptmann M, van de Vijver MJ, Koornstra RH, Bueno-de-Mesquita JM, Linn SC, van't Veer LJ: The predictive value of the 70 -gene signature for adjuvant chemotherapy in early breast cancer. Breast Cancer Res Treat 2010, 120:655-661.

42. Retel VP, Joore MA, Knauer M, Linn SC, Hauptmann M, Harten WH: Costeffectiveness of the 70-gene signature versus St. Gallen guidelines and Adjuvant Online for early breast cancer. Eur J Cancer 2010, 46:1382-1391.

43. Foekens JA, Atkins D, Zhang Y, Sweep FC, Harbeck N, Paradiso A, Cufer T, Sieuwerts AM, Talantov D, Span PN, Tjan-Heijnen VC, Zito AF, Specht K, Hoefler H, Golouh R, Schittulli F, Schmitt M, Beex LV, Klijn JG, Wang Y: Multicenter validation of a gene expression-based prognostic signature in lymph node-negative primary breast cancer. J Clin Oncol 2006, 24:1665-1671

44. Tordai A, Liedtke C, Pusztai L: Metastatic gene signatures and emerging novel prognostic tests in the management of early stage breast cancer. Clin Exp Metastasis 2009, 26:625-632.

45. Sotiriou C, Pusztai L: Gene-expression signatures in breast cancer. N Engl」 Med 2009, 360:790-800.

46. Loi S, Haibe-Kains B, Desmedt C, Wirapati P, Lallemand F, Tutt AM, Gillet C, Ellis P, Ryder K, Reid JF, Daidone MG, Pierotti MA, Berns EM, Jansen MP, Foekens JA, Delorenzi M, Bontempi G, Piccart MJ, Sotiriou C: Predicting prognosis using molecular profiling in estrogen receptor-positive breast cancer treated with tamoxifen. BMC Genomics 2008, 9:239.

47. Symmans WF, Hatzis C, Sotiriou C, Andre F, Peintinger F, Regitnig $P$, Daxenbichler G, Desmedt C, Domont J, Marth C, Delaloge S, Bauernhofer T, Valero V, Booser DJ, Hortobagyi GN, Pusztai L: Genomic index of sensitivity to endocrine therapy for breast cancer. J Clin Oncol 2010, 28:4111-41 19.

48. Hess KR, Anderson K, Symmans WF, Valero V, Ibrahim N, Mejia JA, Booser D, Theriault RL, Buzdar AU, Dempsey PJ, Rouzier R, Sneige N, Ross JS, Vidaurre T, Gómez HL, Hortobagyi GN, Pusztai L: Pharmacogenomic predictor of sensitivity to preoperative chemotherapy with paclitaxel and fluorouracil, doxorubicin, and cyclophosphamide in breast cancer. J Clin Oncol 2006, 24:4236-4244.

49. Tabchy A, Valero V, Vidaurre T, Lluch A, Gomez H, Martin M, Qi Y, BarajasFigueroa L, Souchon E, Coutant C, Doimi FD, Ibrahim NK, Gong Y, Hortobagyi GN, Hess KR, Symmans WF, Pusztai L: Evaluation of a 30-gene paclitaxel, fluorouracil, doxorubicin, and cyclophosphamide chemotherapy response predictor in a multicenter randomized trial in breast cancer. Clin Cancer Res 2010, 16:5351-5361.

50. Hatzis C, Pusztai L, Valero V, Booser DJ, Esserman L, Lluch A, Vidaurre T, Holmes F, Souchon E, Wang H, Martin M, Cotrina J, Gomez H, Hubbard R, Chacón Jl, Ferrer-Lozano J, Dyer R, Buxton M, Gong Y, Wu Y, Ibrahim N, Andreopoulou E, Ueno NT, Hunt K, Yang W, Nazario A, DeMichele A, O'Shaughnessy J, Hortobagyi GN, Symmans WF: A genomic predictor of response and survival following taxane-anthracycline chemotherapy for invasive breast cancer. JAMA 2011, 305:1873-1881.

51. Moulder S, Yan K, Huang F, Hess KR, Liedtke C, Lin F, Hatzis C, Hortobagyi GN, Symmans WF, Pusztai L: Development of candidate genomic markers to select breast cancer patients for dasatinib therapy. Mol Cancer Ther 2010, 9:1120-1127.

52. Habermann JK, Doering J, Hautaniemi S, Roblick UJ, Bündgen NK, Nicorici D, Kronenwett U, Rathnagiriswaran S, Mettu RK, Ma Y, Krüger S, Bruch HP, Auer G, Guo NL, Ried T: The gene expression signature of genomic instability in breast cancer is an independent predictor of clinical outcome. Int $J$ Cancer 2009, 124:1552-1564.

53. Russnes HG, Vollan HK, Lingjaerde OC, Krasnitz A, Lundin P, Naume B, Sørlie T, Borgen E, Rye IH, Langerød A, Chin SF, Teschendorff AE, Stephens PJ, Månér S, Schlichting E, Baumbusch LO, Kåresen R, Stratton MP, Wigler M, Caldas C, Zetterberg A, Hicks J, Børresen-Dale AL: Genomic architecture characterizes tumor progression paths and fate in breast cancer patients. Sci Trans/ Med 2010, 2:38ra47.

54. Carter SL, Eklund AC, Kohane IS, Harris LN, Szallasi Z: A signature of chromosomal instability inferred from gene expression profiles predicts clinical outcome in multiple human cancers. Nat Genet 2006, 38:1043-1048.

55. Chang HY, Sneddon JB, Alizadeh AA, Sood R, West RB, Montgomery K, Chi JT, van de Rijn M, Botstein D, Brown PO: Gene expression signature of fibroblast serum response predicts human cancer progression: similarities between tumors and wounds. PLOS Biol 2004, 2:E7.
56. Chi JT, Wang Z, Nuyten DS, Rodriguez EH, Schaner ME, Salim A, Wang Y, Kristensen GB, Helland A, Børresen-Dale AL, Giaccia A, Longaker MT, Hastie T, Yang GP, van de Vijver MJ, Brown PO: Gene expression programs in response to hypoxia: cell type specificity and prognostic significance in human cancers. PLoS Med 2006, 3:e47.

57. Liu R, Wang X, Chen GY, Dalerba P, Gurney A, Hoey T, Sherlock G, Lewicki J, Shedden $\mathrm{K}$, Clarke MF: The prognostic role of a gene signature from tumorigenic breast-cancer cells. N Eng/ J Med 2007, 356:217-226.

58. Minn AJ, Gupta GP, Siegel PM, Bos PD, Shu W, Giri DD, Viale A, Olshen AB, Gerald WL, Massague J: Genes that mediate breast cancer metastasis to lung. Nature 2005, 436:518-524.

59. Narod SA, Foulkes WD: BRCA1 and BRCA2: 1994 and beyond. Nat Rev Cancer 2004, 4:665-676.

60. Forbes SA, Tang G, Bindal N, Bamford S, Dawson E, Cole C, Kok CY, Jia M, Ewing R, Menzies A, Teague JW, Stratton MR, Futreal PA: COSMIC (the Catalogue of Somatic Mutations in Cancer): a resource to investigate acquired mutations in human cancer. Nucleic Acids Res 2010, 38:D652-657.

61. Bachman KE, Argani P, Samuels Y, Silliman N, Ptak J, Szabo S, Konishi H, Karakas B, Blair BG, Lin C, Peters BA, Velculescu VE, Park BH: The PIK3CA gene is mutated with high frequency in human breast cancers. Cancer Biol Ther 2004, 3:772-775.

62. Carey LA, Perou CM, Livasy CA, Dressler LG, Cowan D, Conway K, Karaca G, Troester MA, Tse CK, Edmiston S, Deming SL, Geradts J, Cheang MC, Nielsen TO, Moorman PG, Earp HS, Millikan RC: Race, breast cancer subtypes, and survival in the Carolina Breast Cancer Study. JAMA 2006, 295:2492-2502.

63. Ding L, Ellis MJ, Li S, Larson DE, Chen K, Wallis JW, Harris CC, McLellan MD, Fulton RS, Fulton LL, Abbott RM, Hoog J, Dooling DJ, Koboldt DC, Schmidt H, Kalicki J, Zhang Q, Chen L, Lin L, Wendl MC, McMichael JF, Magrini VJ, Cook L, McGrath SD, Vickery TL, Appelbaum E, Deschryver K, Davies S, Guintoli T, Lin $L$, et al:: Genome remodelling in a basal-like breast cancer metastasis and xenograft. Nature 2010, 464:999-1005.

64. Shah SP, Morin RD, Khattra J, Prentice L, Pugh T, Burleigh A, Delaney A, Gelmon K, Guliany R, Senz J, Steidl C, Holt RA, Jones S, Sun M, Leung G, Moore R, Severson T, Taylor GA, Teschendorff AE, Tse K, Turashvili G, Varhol R, Warren RL, Watson P, Zhao Y, Caldas C, Huntsman D, Hirst M, Marra MA, Aparicio S: Mutational evolution in a lobular breast tumour profiled at single nucleotide resolution. Nature 2009, 461:809-813.

65. Wang P, Whiteaker JR, Paulovich AG: The evolving role of mass spectrometry in cancer biomarker discovery. Cancer Biol Ther 2009, 8:1083-1094.

66. Yocum AK, Chinnaiyan AM: Current affairs in quantitative targeted proteomics: multiple reaction monitoring-mass spectrometry. Brief Funct Genomic Proteomic 2009 8:145-157.

67. Kuzyk MA, Smith D, Yang J, Cross TJ, Jackson AM, Hardie DB, Anderson NL, Borchers $\mathrm{CH}$ : Multiple reaction monitoring-based, multiplexed, absolute quantitation of 45 proteins in human plasma. Mol Cell Proteomics 2009, 8:1860-1877.

68. Domanski D, Murphy LC, Borchers CH: Assay development for the determination of phosphorylation stoichiometry using multiple reaction monitoring methods with and without phosphatase treatment: application to breast cancer signaling pathways. Anal Chem 2010 82:5610-5620.

69. Leth-Larsen R, Lund R, Hansen HV, Laenkholm AV, Tarin D, Jensen ON, Ditzel $\mathrm{HJ}$ : Metastasis-related plasma membrane proteins of human breast cancer cells identified by comparative quantitative mass spectrometry. Mol Cell Proteomics 2009, 8:1436-1449.

70. Zach O, Lutz D: Tumor cell detection in peripheral blood and bone marrow. Curr Opin Oncol 2006, 18:48-56.

71. Gerges N, Rak J, Jabado N: New technologies for the detection of circulating tumour cells. Br Med Bull 2010, 94:49-64.

72. Pantel K, Alix-Panabieres C, Riethdorf S: Cancer micrometastases. Nat Rev Clin Oncol 2009, 6:339-351.

73. Thurm H, Ebel S, Kentenich C, Hemsen A, Riethdorf S, Coith C, Wallwiener D, Braun S, Oberhoff $C$, Janicke F, Pantel $K$ : Rare expression of epithelial cell adhesion molecule on residual micrometastatic breast cancer cells after adjuvant chemotherapy. Clin Cancer Res 2003, 9:2598-2604.

74. Deng G, Herrler M, Burgess D, Manna E, Krag D, Burke JF: Enrichment with anti-cytokeratin alone or combined with anti-EpCAM antibodies significantly increases the sensitivity for circulating tumor cell detection in metastatic breast cancer patients. Breast Cancer Res 2008, 10:R69.

75. Braun S, Vogl FD, Naume B, Janni W, Osborne MP, Coombes RC, Schlimok G, Diel IJ, Gerber B, Gebauer G, Pierga JY, Marth C, Oruzio D, Wiedswang G, 
Solomayer EF, Kundt G, Strobl B, Fehm T, Wong GY, Bliss J, Vincent-Salomon A, Pantel K: A pooled analysis of bone marrow micrometastasis in breast cancer. N Engl J Med 2005, 353:793-802.

76. De Giorgi U, Valero V, Rohren E, Mego M, Doyle GV, Miller MC, Ueno NT, Handy BC, Reuben JM, Macapinlac HA, Hortobagyi GN, Cristofanilli M: Circulating tumor cells and bone metastases as detected by FDG-PET/CT in patients with metastatic breast cancer. Ann Oncol 2010, 21:33-39.

77. Fehm T, Müller V, Aktas B, Janni W, Schneeweiss A, Stickeler E, Lattrich C, Löhberg CR, Solomayer E, Rack B, Riethdorf S, Klein C, Schindlbeck C, Brocker K, Kasimir-Bauer S, Wallwiener D, Pantel K: HER2 status of circulating tumor cells in patients with metastatic breast cancer: a prospective, multicenter trial. Breast Cancer Res Treat 2010, 124:403-412.

78. Meng S, Tripathy D, Frenkel EP, Shete S, Naftalis EZ, Huth JF, Beitsch PD, Leitch M, Hoover S, Euhus D, Haley B, Morrison L, Fleming TP, Herlyn D, Terstappen LW, Fehm T, Tucker TF, Lane N, Wang J, Uhr JW: Circulating tumor cells in patients with breast cancer dormancy. Clin Cancer Res 2004, 10:8152-8162.

79. Pantel K, Brakenhoff RH, Brandt B: Detection, clinical relevance and specific biological properties of disseminating tumour cells. Nat Rev Cancer 2008, 8:329-340.

80. Leary RJ, Kinde I, Diehl F, Schmidt K, Clouser C, Duncan C, Antipova A, Lee C, McKernan K, De La Vega FM, Kinzler KW, Vogelstein B, Diaz LA Jr, Velculescu VE: Development of personalized tumor biomarkers using massively parallel sequencing. Sci Trans/ Med 2010, 2:20ra14.

81. Stephens PJ, McBride DJ, Lin ML, Varela I, Pleasance ED, Simpson JT, Stebbings LA, Leroy C, Edkins S, Mudie L, Greenman CD, Jia M, Latimer C, Teague JW Lau KW, Burton J, Quail MA, Swerdlow H, Churcher C, Natrajan R, Sieuwerts AM, Martens JW, Silver DP, Langerød A, Russnes HE, Foekens JA, Reis-Filho JS, van't Veer L, Richardson AL, Børresen-Dale AL, et al.: Complex landscapes of somatic rearrangement in human breast cancer genomes. Nature 2009, 462:1005-1010.

82. Jones SJ, Laskin J, Li YY, Griffith OL, An J, Bilenky M, Butterfield YS, Cezard T, Chuah E, Corbett R, Fejes AP, Griffith M, Yee J, Martin M, Mayo M, Melnyk N, Morin RD, Pugh TJ, Severson T, Shah SP, Sutcliffe M, Tam A, Terry J, Thiessen N, Thomson T, Varhol R, Zeng T, Zhao Y, Moore RA, Huntsman DG, et al:: Evolution of an adenocarcinoma in response to selection by targeted kinase inhibitors. Genome Biol 2010, 11:R82.

83. Birdwell RL, Mountford CE, Iglehart JD: Molecular imaging of the breast. AJR Am J Roentgenol 2009, 193:367-376.

84. Stanwell P, Gluch L, Clark D, Tomanek B, Baker L, Giuffre B, Lean C, Malycha P,
Mountford C: Specificity of choline metabolites for in vivo diagnosis of breast cancer using 1H MRS at 1.5 T. Eur Radiol 2005, 15:1037-1043.

85. Pan L, Han Y, Sun X, Liu J, Gang H: FDG-PET and other imaging modalities for the evaluation of breast cancer recurrence and metastases: a metaanalysis. J Cancer Res Clin Oncol 2010, 136:1007-1022.

86. Basu S, Chen W, Tchou J, Mavi A, CermikT, Czerniecki B, Schnall M, Alavi A: Comparison of triple-negative and estrogen receptor-positive/ progesterone receptor-positive/HER2-negative breast carcinoma using quantitative fluorine-18 fluorodeoxyglucose/positron emission tomography imaging parameters: a potentially useful method for disease characterization. Cancer 2008, 112:995-1000.

87. Dietzel M, Baltzer PA, Vag T, Groschel T, Gajda M, Camara O, Kaiser WA: Application of breast MRI for prediction of lymph node metastases systematic approach using 17 individual descriptors and a dedicated decision tree. Acta Radiol 2010, 51:885-894.

88. Ma J, Costelloe CM, Madewell JE, Hortobagyi GN, Green MC, Cao G, Sun F, Kundra V: Fast dixon-based multisequence and multiplanar MRI for wholebody detection of cancer metastases. J Magn Reson Imaging 2009, 29:1154-1162.

89. Cai W, Chen X: Nanoplatforms for targeted molecular imaging in living subjects. Small 2007, 3:1840-1854.

90. Kramer-Marek G, Kiesewetter DO, Capala J: Changes in HER2 expression in breast cancer xenografts after therapy can be quantified using PET and (18)F-labeled affibody molecules. J Nucl Med 2009, 50:1131-1139.

91. Khatcheressian JL, Wolff AC, Smith TJ, Grunfeld E, Muss HB, Vogel VG, Halberg F, Somerfield MR, Davidson NE: American Society of Clinical Oncology 2006 update of the breast cancer follow-up and management guidelines in the adjuvant setting. J Clin Oncol 2006, 24:5091-5097.

92. Creative Commons Attribution 3.0 Unported [http://creativecommons.org/ licenses/by/3.0/deed.en]

93. Creative Commons Attribution-Share Alike 3.0 Unported [http:// creativecommons.org/licenses/by-sa/3.0/deed.en]

doi:10.1186/bcr2923

Cite this article as: Griffith OL, Gray JW: 'Omic approaches to preventing or managing metastatic breast cancer. Breast Cancer Research 2011, 13:230. 